\title{
PENGARUH CASH HOLDING, RESIKO KEUANGAN, DAN UMUR PERUSAHAAN TERHADAP INCOME SMOOTHING Muliani Mangngalla', ${ }^{,}$Kartini' $^{2}$ \\ Universitas Hasanuddin ${ }^{1,2}$ mulianimangngallaak@gmail.com
}

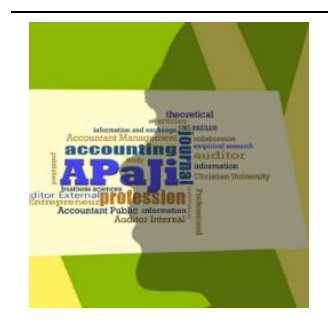

e-ISSN 2686-0058

p-ISSN 2715-7695

Informasi Artikel

Tanggal masuk

30 Oktober 2020

Tanggal revisi

15 November 2020

Tanggal diterima

26 Desember 2020

Kata Kunci: cash holding ${ }^{1}$ financial risk $^{2}$ self-efficacy ${ }^{3}$ company age $e^{4}$ income smoothing 5

\begin{abstract}
Income smoothing is one of the steps taken by management so that the accounting profit from the company's financial statements has lower fluctuation (smooth). This action is due to market conditions that tend to respond more to financial information which has an increasing nature. This is done indirectly for the welfare of its investors (agency theory). This study aims to determine the effect of cash holding, financial risk, and company age on income smoothing. By using banking companies listed on the Indonesia Stock Exchange for the period 2017-2019 as research objects. The research method used is a regression analysis method using a quantitative approach. The research sample was selected by purposive sampling technique and obtained 60 observational data. The results of this study indicate that simultaneously and partially financial risk and company age have an effect on income smoothing while cash holding has no effect on income smoothing. The financial risk variable has a negative effect, while the company age variable has a positive effect on income smoothing.
\end{abstract}

\begin{abstract}
Abstrak: Income smoothing merupakan salah satu langkah yang dilakukan oleh manajemen agar laba akuntansi dari laporan keuangan perusahaan memiliki fluktuasi yang lebih rendah (smooth). Tindakan ini disebabkan karena kondisi pasar yang cenderung lebih merespon informasi keuangan yang memiliki sifat meningkat. Hal tersebut dilakukan manajemen untuk mensejahterakan investornya (teori agensi) secara tidak langsung. Penelitian ini bertujuan untuk mengetahui pengaruh cash holding, resiko keuangan, dan umur perusahaan terhadap income smoothing. Dengan menggunakan perusahaan perbankan yang terdaftar di Bursa Efek Indonesia periode 2017-2019 sebagai objek penelitian. Metode penelitian yang digunakan adalah metode analisis regresi dengan menggunakan pendekatan kuantitatif. Sampel penelitian dipilih dengan teknik purposive sampling dan diperoleh 60 data pengamatan. Hasil dari penelitian ini menunjukkan bahwa secara simultan dan parsial resiko keuangan dan umur perusahaan berpengaruh terhadap income smoothing sedangkan cash holding tidak berpengaruh terhadap income smoothing. Variabel resiko keuangan berpengaruh secara negatif sedangkan variabel umur perusahaan berpengaruh secara positif terhadap income smoothing.
\end{abstract}

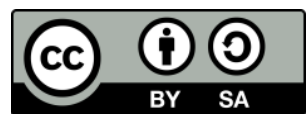

\section{PENDAHULUAN}

Income smoothing adalah fenomena yang sering terjadi sebagai upaya manajemen dalam mengurangi fluktuasi laba yang akan dilaporkan. Laporan keuangan menjadi cerminan dari kinerja perusahaan yang akan digunakan oleh pihak eksternal dalam pengambilan keputusan (Eviyanti et all, 2019). Laba menjadi salah satu yang menjadi perhatian pihak eksternal dalam laporan keuangan sehingga laba perusahaan menjadi parameter untuk menilai kinerja manajemen perusahaan. Laba merupakan salah satu ukuran yang sering dijadikan tolak ukur oleh pihak berkepentingan dalam mengukur kinerja perusahaan, disamping itu informasi laba juga membantu 
pemilik atau pihak lain dalam menaksir rentabilitas (earning power) perusahaan di masa yang akan dating (Sanjaya \& Suryadi, 2018).

Informasi laba pada umumnya merupakan hasil yang dicapai oleh perusahaan dari operasinya dalam suatu periode tertentu. Bettie et al (1994) dalam Ni Nyoman (2012) menguraikan bahwa kesempatan manajemen untuk melakukan manajemen laba dimotivasi oleh perhatian investor yang seringkali hanya berpusat pada informasi laba dan bukan pada prosedur untuk menghasilkan laba tersebut. Salah bentuk umum dari manajemen laba adalah income smoothing (perataan laba.

Tindakan perataan laba (income smoothing) merupakan kejadian yang sering terjadi dikarenakan manajemen berupaya untuk mengurangi laba yang dilaporkan (Nasir et all, 2002 dalam William dan Lukman, 2018). Income smoothing merupakan sebuah praktik yang digunakan oleh manajemen baik secara artificial maupun riil untuk mengurangi fluktuasi laba yang dilaporkan sehingga mencapai tren atau level yang stabil dari periode sebelumnya (Mambraku \& Hadiprajitno, 2014).

Penelitian mengenai faktor-faktor yang berpengaruh terhadap perataan laba merupakan salah satu hal yang cukup menarik dan telah banyak dilakukan, namun hasil dari penelitian tersebut berbeda walaupun mengukur variabel yang sama. Praktik manajemen laba dapat dipengaruhi oleh beberapa faktor yang mendorong manajer untuk melakukan tindakan perataan laba. Penelitian terdahulu telah menguji bahwa faktor-faktor yang berpengaruh terhadap perataan laba diantaranya profitabilitas, risiko keuangan, nilai perusahaan, struktur kepemilikan, leverage operasi, cash holding dan ukuran perusahaan (Sanjaya \& Suryadi, 2018).

Penelitian ini sangat menarik untuk dilakukan di Indonesia karena Indonesia merupakan salah satu sampel yang berada pada urutan 15 dari 31 negara yang melakukan praktik manajemen laba ini (Erika, 2014 dalam Wulan, 2018). Penelitian ini hanya berfokus pada perusahaan perbankan untuk menghindari bias terhadap hasil penelitian jika menggunakan perusahaan yang berbeda. Perusahaan perbankan digunakan secara khusus karena perusahaan perbankan lebih banyak melakukan income smoothing dibandingkan perusahaan non keuangan, hal ini disebabkan karena perusahaan perbankan merupakan jenis perusahaan yang memiliki resiko tinggi. Selain itu, pada stabilitas sistem keuangan dan sistem perbankan negara, bank menjadi cerminan kepercayaan pemegang saham.

Berdasarkan uraian diatas, maka peneliti tertarik untuk melakukan penelitian dengan judul "Pengaruh Cash Holding, Resiko Keuangan, Dan Umur Perusahaan Terhadap Income Smoothing"

\section{KAJIAN LITERATUR DAN PENGEMBANGANHIPOTESIS Teori Agensi}

Agency theory adalah teori yang menguraikan perbedaan kepentingan antara agent dan principal sehingga menyebabkan timbulnya konflik. Teori agensi menjelaskan bahwa hubungan keagenan terjadi atas persetujuan antara dua pihak, yakni principal sebagai pemilik dengan agent sebagai manajemen, dalam hal ini principal memberikan wewenang kepada agent untuk mengambil keputusan atas nama principal (Jensen dan Meckling, 1976).

Dalam hubungan keagenan, manajer memiliki asimetri informasi terhadap pihak eksternal seperti kreditor dan investor. Hal ini terjadi pada saat manajer memiliki lebih banyak informasi internal perusahaan dibandingkan pihak eksternal dan bahkan lebih cepat untuk mengetahui informasi tersebut. Teori agensi (agency theory) menyatakan bahwa praktik income smoothing terjadi karena dipengaruhi oleh konflik kepentingan antara manajemen sebagai agent dan pemilik 
sebagai principal yang muncul ketika diantara pihak sama-sama berusaha untuk mencapai dan mempertahankan tingkat kepentingan dan kemakmurannya (Novianti dan Yuyetta, 2011)

Dengan adanya perbedaan kepentingan antara kedua pihak, terutama dari pihak manajer yang kinerjanya dinilai berdasarkan laba yang dilaporkan, menyebabkan manajer berusaha mencapai keinginannya tersebut dengan memanipulasi laba akuntansi dalam laporan keuangan, yakni dengan melakukan manajemen laba dan salah satu bentuk manajemen laba tersebut adalah income smoothing (perataan laba) (Santoso dan Salim, 2012)

\section{Perataan Laba (Income Smoothing)}

Tindakan yang secara sengaja dilakukan oleh manajer perusahaan untuk mengurangi dampak fluktuasi laba yang terlalu tinggi pada laporan keuangan dalam periode berjalan selama tindakan tersebut sesuai dengan prinsip akuntansi dan manajemen yang baik disebut income smoothing (William dan Lukman, 2018). Umumnya, perusahaan melakukan perataan laba (income smoothing) karena tidak dapat mencapai hasil laba yang stabil, dimana tindakan ini berfokus pada hasil income perusahaan setiap tahun. Menurut Ni Nyoma (2012) tindakan perataan laba timbul karena manajemen yang diberikan kebebasan untuk memilih berbagai metode akuntansi dengan tujuan untuk: (1) Mencapai keuntungan dalam pajak. (2) Mendapatkan kesan yang baik dari pemilik dan kreditor terhadap kinerja manajemen. (3) Mengurangi fluktuasi pada pelaporan laba dan mengurangi resiko. (4) Menghasilkan pertumbuhan keuntungan yang stabil. (5) Menjaga jabatan mereka dalam perusahaan.

\section{Cash Holding}

Kas (cash holding) merupakan aktiva lancar yang paling likuid dan yang digunakan oleh manajer dalam menjalankan operasional perusahaan. Kebijakan perusahaan untuk memegang kas adalah langkah dalam melindungi perusahaan dari cash shortfall (Sanjaya \& Suryadi, 2018). Cash holding didefinisikan sebagai arus kas bebas yang dapat digunakan manajer untuk memenuhi kepentingannya atas kebutuhan dari investor, sehingga hal ini dapat memperburuk konflik interest diantara kedua pihak (Jensen, 2015).

\section{Resiko Keuangan}

Menurut Noviana dan Yuyeta (2011) resiko keuangan merupakan proporsi penggunaan utang untuk membiayai investasi (asset bersih). Risiko keuangan (financial leverage) memandingkan antar hutang dan aktiva yang menunjukkan beberapa bagian aktiva yang digunakan untuk menjamin hutang. Risiko keuangan juga tercermin dalam faktor-faktor seperti leverage neraca, transaksi off-balance sheet, jatuh tempo pembayaran utang, kewajiban kontrak, likuiditas, dan hal-hal lainnya yang mengurangi fleksibilitas keuangan (Agusth, 2018).

\section{Umur Perusahaan}

Menurut Wildham (2013) umur perusahaan merupakan suatu hal yang menjadi bahan pertimbangan pemegang saham dalam melakukan penanaman modal, hal ini karena umur perusahaan mencerminkan survive perusahaan dan sebagai bukti bahwa perusahaan bisa bersaing dan dapat mengambil kesempatan bisnis didalam perekonomian. Secara teoritis, perusahaan yang telah lama berdiri akan dlebih dipercaya oleh pemegang saham (investor) dari pada perusahaan yang saja berdiri, hal ini dikarenakan perusahaan yang telah lama berdiri dianggap akan menghasilkan laba yang lebih tinggi dibandingkan perusahaan yang berdiri (Sellah dan Vinola, 2019). Perusahaan yang baru didirikan tentu akan berusaha mendapatkan laba yang tinggi agar untuk dapat menghasilkan citra yang baik dari berbagai pihak. 


\section{KERANGKA PEMIKIRAN}

Kerangka pemikiran dalam penelitian ini, yaitu:

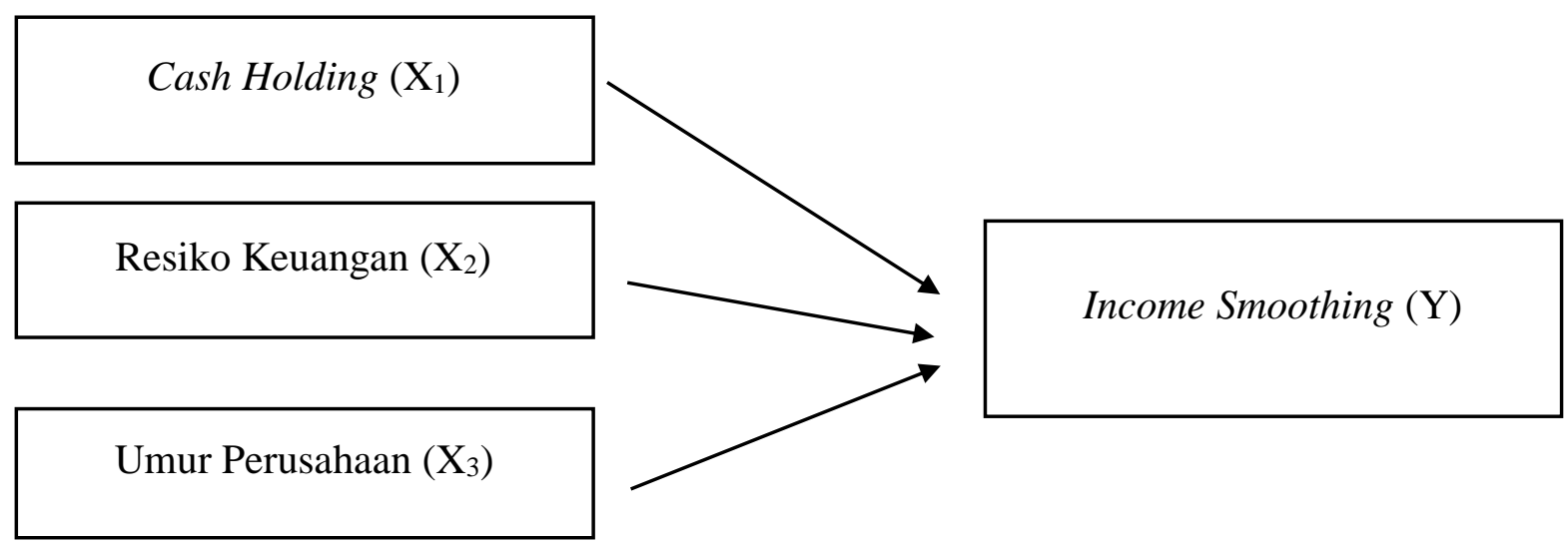

Hipotesis dari kerangka pemikiran dalam penelitian ini, yaitu:

Pengaruh Cash Holding Terhadap Income Smooting

Menurut Olivia dan Herlin (2019) kas merupakan salah satu aktiva lancar yang siap untuk dikonversikan menjadi aset lainnya dan juga sangat mudah untuk disembunyikan, dipindahkan, dan banyak diinginkan. Oleh karena itu, kas merupakan aset yang sangat mungkin untuk digunakan dan dibelanjakan secara semena-mena oleh pihak-pihak dalam perusahaan dan dalam konteks ini manajemenlah yang paling mungkin untuk melakukannya. Dalam penelitian yang dilakukan oleh Prilliy dan Mawar (2015) mengatakan bahwa terdapat pengaruh cash holding terhadap income smoothing, sedangkan pada penelitian yang dilakukan oleh William dan Lukman (2018)) dan yang dilakukan oleh Wulan (2019) menunjukkan bahwa cash holding tidak berpengaruh terhadap income smoothing. Berdasarkan uraian diatas, maka penelitian ini mengajukan hipotesis, yaitu:

$\mathrm{H}_{1}$ : Cash Holding berpengaruh positif terhadap income smoothing.

\section{Pengaruh Resiko Keuangan Terhadap Income Smoothing}

Resiko keuangan merupakan perbandingan utang yang dimiliki dalam perusahaan sebagai sumber pendanaan dan aktiva yang dimiliki untuk dijaminkan. Resiko keuangan yang tinggi berdampak buruk juga bagi penilaian investor, pada keputusan yang memengaruhi investasi mereka maka resiko tersebut menjadi bahan pertimbangan yang akan dipakai investor untuk meprediksi tingkat keuntungan yang yang didapat dan calon investor akan menghindari perusahaan yang memiliki risiko keuangan yang tinggi karena tidak mempunyai prospek di masa depan yang menjanjikan (Agusth, 2018). Penelitian yang dilakukan oleh Ida Bagus dan Ida Ayu (2014) menyatakan bahwa resiko keuangan berpengaruh terhadap income smoothing, berbeda dengan itu penelitian yang dilakukan oleh Tevi et all (2019) menyatakan bahwa resiko keuangan tidak berpengaruh terhadap income smoothing. Berdasarkan uraian diatas, maka penelitian ini mengajukan hipotesis, yaitu:

$\mathrm{H}_{2}$ : Resiko keuangan berpengaruh positif terhadap income smoothing.

\section{Pengaruh Umur Perusahaan Terhadap Income Smoothing}

Umur perusahaan merupakan lamanya suatu perusahaan dibentuk, yakni apakah perusahaan tersebut telah lama atau baru saja didirikan. Perusahaan yang telah lama berdiri memiliki dorongan yang lebih besar untuk melakukan perataan laba karena telah memiliki pengalaman dalam mengelola bisnisnya dibandingkan dengan manajemen sebelumnya dengan tujuan untuk 
mengurangi fluktuasi laba di masa depan (Merry, 2006 dalam Sellah dan Vinola, 2019). Penelitian yang dilakukan oleh Sartika dan Rice (2013) menyatakan bahwa umur perusahaan berpengaruh terhadap income smoothing, sedangkan penelitian yang dilakukan oleh Olivia dan Herlin (2019) menyatakan bahwa umur perusahaan tidak berpengaruh terhadap income smoothing. Berdasarkan uraian diatas, maka penelitian ini mengajukan hipotesis, yaitu:

$\mathrm{H}_{3}$ : Umur perusahaan berpengaruh positif terhadap income smoothing.

\section{METODE PENELITIAN}

\section{Populasi, Sampel dan Metode Pengambilan Sampel}

Penelitian ini merupakan jenis penelitian kuantitatif, dimana populasi yang digunakan dalam penelitian ini adalah perusahaan perbankan yang terdaftar di Bursa Efek Indonesia (BEI) periode 2017-2019.

Periode data perusahaan yang digunakan selama 3 tahun terakhir karena data ini merupakan data terbaru perusahaan yang mencerminkan gambaran terkini keadaan dan kinerja keuangan perusahaan. Dengan teknik sampel yang digunakan purposive sampling, memiliki kriteria: perusahaan perbankan yang menerbitkan laporan keuangan secara dari tahun 2017-2019, perusahaan menerbitkan laporan keuangan dengan mata uang rupiah, dan perusahaan memiliki data yang lengkap terkait dengan variabel dalam penelitian ini.

\section{Definisi Operasional Variabel}

Variabel operasional dalam penelitian ini terdiri dari cash holding, resiko keuangan, dan umur perusahaan yang merupakan variabel independen dan income smoothing sebagai variabel dependen.

\section{Income Smoothing}

Income smoothing (perataan laba) adalah upaya yang dilakukan manajemen untuk mengurangi fluktuasi laba pada perusahaan (Yulia, 2013). Variabel ini diukur menggunakan Indeks Eckel. Apabila indeks income smoothing perusahaan bernilai < 1 maka diberikan nilai 1 dan perusahaan apabia indeks income smoothing perusahaan $\geq 1$ maka akan diberikan nilai 0 . Untuk menetukan perataan laba maka Eckel menggunakan Coefficient Variation (CV) variabel penghasilan dan variabel penghasilan bersih. Adapun perhitungan indeks eckel dirumuskan sebagai berikut:

$$
\begin{aligned}
& \text { Indeks Perataan Laba }=\frac{C V \Delta I}{C V \Delta S} \\
& \mathrm{CV} \Delta \mathrm{I}=\frac{\sqrt{\sum(\Delta I i-\Delta I)^{2}} / n-1}{\Delta \bar{I}} \\
& \mathrm{CV} \Delta \mathrm{I}=\frac{\sqrt{\sum(\Delta S i-\Delta S)^{2}} / n-1}{\Delta \check{S}}
\end{aligned}
$$

Sumber : Dewi Andriani, 2020

Keterangan:

$\mathrm{CV}$ : Koefisien variansi dari variabel

$\Delta I$ : Perubahan lanba periode $\mathrm{i}$

$\Delta \mathrm{S}:$ Perubahan penjualan pada periode $\mathrm{i}$

I : Rata-rata laba

$S$ : Rata-rata penjualan

$\mathrm{n}$ : Jumlah tahun yang diteliti 


\section{Cash Holding}

Cash holding merupakan arus kas bebas yang dapat digunakan manajer dalam memenuhi kepentingan manajer atas kebutuhan dari investor, yang dapat memperburuk konflik interest diantara kedua pihak (Jensen, 2015). Variabel cash holding diukur dengan menggunakan kas dan setara kas dibagi total aktiva, atau dapat dirumuskan sebagai berikut:

$$
\text { Cash Holding }=\frac{\text { Kas }+ \text { Setara Kas }}{\text { Total Asset }}
$$

Sumber : Yashinta, 2013 dalam Wulan, 2018

\section{Resiko Keuangan}

Resiko keuangan adalah seberapa perusahaan bergantung pada pembiayaan eksternal (Bank) untuk mendukung operasi yang sedang berlangsung dan mengurangi fleksilibitas keuangan (Riadianto, 2015 dalam Agusth, 2018). Resiko keuangan yang digunakan untuk menilai penggunaan pembiayaan adalah tingkat Debt Asset Ratio (DAR), adapun pengukurannya adalah sebagai berikut:

\section{Umur Perusahaan}

$$
\text { Cash Holding }=\frac{\text { Total Liabilitas }}{\text { Total Asset }}
$$

Sumber : Agusth (2018)

Umur perusahaan merupakan lama berdirinya suatu perusahaan. Menurut Wildham (2013) variabel umur perusahaan dihitung dengan mengurangi tahun sejak perusahaan perbankan listing di Bursa Efek Indonesia (BEI) dengan tahun dilakukannya penelitian (2020).

\section{Teknik Analisis Data}

Seluruh penyajian serta penganalisis data dalam penelitian ini menggunakan bantuan dari program Statistical Package for Social Science (SPSS) 25 for windows.

\section{Uji Asumsi Klasik}

Uji asumsi klasik dilakukan untuk mengetahui kelayakan data untuk dianalisis, karena tidak semua data dapat dianalisis dengan regresi. Adapun uji asumsi klasik yang digunakan dalam penelitian ini adalah:

\section{1) Uji Normalitas atau Distribusi Normal}

Uji normalitas bertujuan untuk menguji apakah model dalam regresi variabel independen dan variabel dependen berdistribusi normal atau tidak. Penelitian ini menganalisis grafik "normal probability report plot" untuk melihat kenormalan data, dimana apabila garis diagonal diikuti oleh data sesungguhnya maka distribusi data dapat dikatakan normal.

\section{2) Uji Multikolinearitas}

Uji multikolinearitas bertujuan untuk menguji apakah dalam model regresi terdapat korelasi antar variabel independen (Ghozali, 2016:103). Adapun nilai cut off umum yang digunakan dalam menunjukkan ada tidaknya multikolinieritas, yaitu nilai dari tolerance $\leq 0,10=$ sama nilai VIF $\geq$ 10 (Ghozali, 2011).

\section{3) Uji Autokorelasi}

Uji autokorelasi merupakan keadaan dimana terjadi korelasi antara faktor penganggu (error term) pada periode terganggu dengan faktor penganggu pada periode lain. Untuk dapat mendeteksi ada tidaknya keberadaan autokorelasi dalam regresi, maka salah satu cara yang dapat digunakan, yaitu dengan uji Durbin-Watson. Adapun kriteria yang digunakan dalam pengambilan keputusan untuk uji Durbin-Watson adalah lebih besar dari 1 atau lebih kecil dari 3. 


\section{4) Uji Heteroskedastisitas}

Heteroskedastisitas adalah varians variabel dalam model tidak sama (konstan). Penelitian ini menggunakan uji glejser untuk mendeteksi keberadaan uji heterokedastisitas. Adapun kritera pengujiannya adalah jika masing-masing dari variabel memiliki nilai signifikan hitung (p-value) lebih besar dari alpha ( $\alpha=0,05$ atau 5\%), maka dapat disimpulkan bahwa tidak ada masalah heteroskedastisitas,

\section{Uji t (Uji Signifikan Parsial)}

Uji statistik t pada dasarnya menunjukkan seberapa jauh pengaruh satu variabel independen secara parsial dalam menejelaskan variansi variabel dependen (Ghozali, 2016). Kriteria pengujian signifikansi parsial antara lain:

Uji statistik t pada dasarnya menujukan seberapa jauh pengaruh satu variabel indepnden secara parsial dalam menerangkan variasi variabel dependen (Ghozali, 2016:97). Kriteria pengujian uji statistik t antara lain:

a. Jika nilai signifikansi $\mathrm{t}>0,05$ maka hipotesis ditolak (koefisien regresi tidak signifikan). Hal ini berarti bahwa secara parsial variabel independen tidak berpengaruh terhadap variabel dependen.

b. Jika nilai signifikansi $\mathrm{t} \leq 0,05$ maka hipotesis diterima (koefisien regresi signifikan). Ini berarti secara parsial variabel independen berpengaruh terhadap variabel dependen.

\section{Uji Regresi Linear Berganda}

Analisis regresi linear berganda merupakan hubungan secara linear dua atau lebih variabel independen $\left(\mathrm{X}_{1}, \mathrm{X}_{2} \ldots . . \mathrm{X}_{\mathrm{n}}\right)$ dengan variabel dependen $(\mathrm{y})$ untuk meramalkan bagaimana keadaan variabel dependen apabila dua atau lebih variabel independen dimanipulasi atau diubah nilainya (Sugiyono, 2017). Adapun persamaan regresi linear berganda yang digunakan dalam penelitian ini dirumuskan sebagai berikut:

Keterangan :

$$
\text { Income Smoothing }=\alpha+\beta_{1} \mathrm{CH}+\beta_{2} \mathrm{DAR}+\beta_{3} \mathrm{FA}_{+}+\mathrm{e}
$$

$\mathrm{Y}=$ income smoothing

$\alpha=$ konstanta

$\beta_{1-3}=$ koefisien regresi

$\mathrm{CH}=$ cash holding

$\mathrm{DAR}=$ resiko keuangan

$\mathrm{FA}=$ umur perusahaan

e $\quad=$ kesalahan residual (error)

\section{Uji F (Uji Signifikan Simultan)}

Uji simultan bertujuan untuk menunjukkan apakah semua variabel independen atau bebas yang dimasukkan ke dalam model memiliki pengaruh secara bersama-sama terhadap variabel dependen. Uji F dilakukan dengan menggunakan tingkat signifikansi 0,05 ( $\alpha=5 \%)$, maka model ini dikatakan fit dengan data observasi atau variabel dependen (Ghozali, 2016:96).

\section{Koefisien Determinasi $\left(\mathbf{R}^{2}\right)$}

Koefisien ini digunakan untuk mengukur seberapa jauh model bisa menerangkan variansi pada variabel dependen. Nilai koefisien determinasi berkisar diantara 0 dan 1 . Apabila nilai $\mathrm{R}^{2}$ rendah maka kemampuan variabel independen dalam menjelaskan variansi variabel dependen itu juga rendah. Semakin dekat nilai dengan 1 maka semakin banyak informasi yang diberikan oleh variabel independen untuk memprediksi variabel dependen (Ghozali, 2016). 


\section{HASIL DAN PEMBAHASAN \\ Hasil Penentuan Sampel}

Penelitian ini menggunakan sampel perusahaan perbankan yang terdaftar di Bursa Efek Indonesia tahun 2017-2019. Dengan menggunakan pendekatan purposive sampling, diperoleh sampel sebanyak 60.

\section{Pengujian dan Hasil Analisis Data} Hasil Analisis Statistik Deskriptif

\section{Tabel 4.1}

\section{Hasil Uji Statistik Deskriptif}

\begin{tabular}{|c|c|c|c|c|c|}
\hline \multicolumn{6}{|c|}{ Descriptive Statistics } \\
\hline & $\mathrm{N}$ & Minimum & Maximum & Mean & Std. Deviation \\
\hline CASH HOLDING & 60 & .07 & .31 & .1495 & .05786 \\
\hline RESIKO KEUANGAN & 60 & .08 & .93 & .8005 & .14622 \\
\hline UMUR PERUSAHAAN & 60 & 5.00 & 38.00 & 15.7000 & 8.12258 \\
\hline INCOME SMOOTHING & 60 & -9.42 & 11.72 & .9198 & 3.88090 \\
\hline Valid N (listwise) & 60 & & & & \\
\hline
\end{tabular}

Sumber: Data yang diolah peneliti (output SPSS 25)

Dari hasil uji statistik deskriptif pada tabel di atas, menunjukkan bahwa income smoothing memiliki rentang nilai dari -9.42-11.72. Variabel cash holding antara 0.07-0.31, variable resiko keuangan memiliki rentang nilai dari 0.08-0. 93 sedangkan variabel umur perusahaan memiliki rentan nilai dari 5.00-38.00.

\section{Uji Asumsi Klasik}

\section{Uji Normalitas}

Berdasarkan hasil output dari pengujian normalitas dengan grafik adalah sebagai berikut:

\section{Grafik 4.1}

\section{Hasil Uji Normalitas}

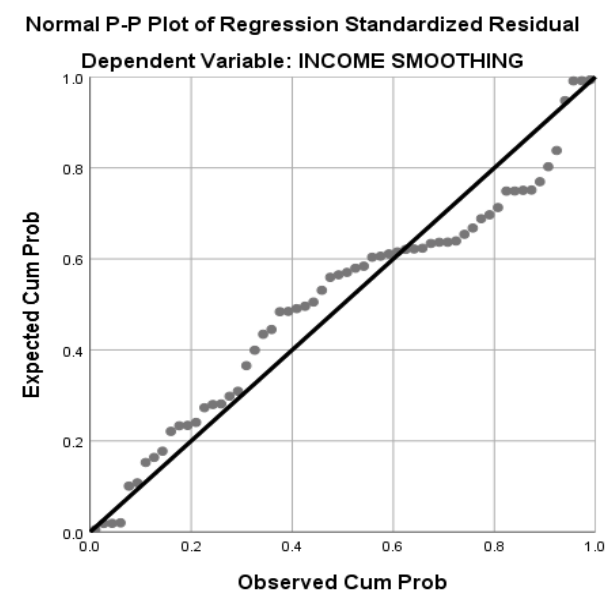

Sumber: Data yang diolah peneliti (output SPSS 25)

Berdasarkan tabel uji normalitas di atas menunjukkan bahwa data sesungguhnya mendekati garis diagonal. Dengan demikian, dapat disimpulkan bahwa data dalam penelitian ini berdistribusi normal. 


\section{Uji Multikolinearitas}

Tabel 4.2

Hasil Uji Multikolinearitas

\begin{tabular}{|c|c|c|c|}
\hline \multirow{2}{*}{ Variabel } & \multicolumn{2}{|c|}{ Collinearity Statistics } & \multirow{2}{*}{ Kesimpulan } \\
\cline { 2 - 3 } & Tolerance & VIF & \\
\hline Cash Holding & .756 & 1.323 & Tidak terjadi multikolinearitas \\
\hline Resiko Keuangan & .847 & 1.181 & Tidak terjadi multikolinearitas \\
\hline $\begin{array}{c}\text { Umur } \\
\text { Perusahaan }\end{array}$ & .701 & 1.427 & Tidak terjadi multikolinearitas \\
\hline
\end{tabular}

Sumber: Data yang diolah peneliti

Tabel di atas menunjukkan bahwa pada model regresi diketahui nilai tolerance dari 3 variabel yaitu cash holding, resiko keuangan, dan umur perusahaan adalah nilai tolerance $>0,10$ atau sama dengan nilai VIF < 10. Hasil pengujian ini mengindikasikan bahwa dalam model-model regresi yang digunakan dalam penelitian ini tidak terjadi gejala multikolinearitas.

Uji Autokorelasi

Tabel 4.3

Hasil Uji Autokorelasi

\begin{tabular}{|c|c|c|}
\hline Nilai Durbin-Watson & Jumlah Sampel & Kesimpulan \\
\hline $\mathbf{2 . 2 5 2}$ & 60 & Tidak terjadi autokorelasi \\
\hline
\end{tabular}

Sumber: Data yang diolah peneliti

Berdasarkan dari hasil analisis terhadap autokorelasi diatas, nilai Durbin-Watson diperoleh sebesar 2.252. Hal ini berarti tidak terjadi autokorelasi dalam penelitian ini.

Uji Heteroskedastisitas

Tabel 4.4

Hasil Uji Heteroskedastisitas

\begin{tabular}{|c|c|c|}
\hline Variabel & Signifikansi & Kesimpulan \\
\hline Cash Holding & 1.323 & Tidak terjadi heteroskedastisitas \\
\hline Resiko Keuangan & 1.181 & Tidak terjadi heteroskedastisitas \\
\hline Umur Perusahaan & 1.427 & Tidak terjadi heteroskedastisitas \\
\hline
\end{tabular}

Sumber: Data yang diolah peneliti

Berdasarkan tabel diatas, dapat diketahui bahwa nilai signifikansi cash holding, resiko keuangan, dan umur perusahaan lebih besar dari 0,05 maka dapat disimpulkan bahwa tidak terjadi masalah heteroskedastisitas dalam model regresi.

Pengujian Parsial (Uji T)

\begin{tabular}{|c|c|c|c|c|c|c|}
\hline & & Hasil U & $\begin{array}{l}\text { Tabel } 4.5 \\
\text { ji Signifikan } \\
\text { Coefficients }\end{array}$ & i (T) & & \\
\hline & & $\begin{array}{r}\text { Unstan } \\
\text { Coeff }\end{array}$ & $\begin{array}{l}\text { lardized } \\
\text { cients }\end{array}$ & $\begin{array}{l}\text { Standardized } \\
\text { Coefficients }\end{array}$ & $\mathrm{t}$ & Sig. \\
\hline & & $\mathrm{B}$ & Std. Error & Beta & & \\
\hline 1 & (Constant) & 9.430 & 2.508 & & 3.761 & .000 \\
\hline & CASH HOLDING & 11.926 & 8.181 & .178 & 1.458 & .150 \\
\hline & RESIKO KEUANGAN & -16.874 & 3.058 & -.636 & -5.518 & .000 \\
\hline & UMUR PERUSAHAAN & .205 & .061 & .428 & 3.383 & .001 \\
\hline
\end{tabular}

a. Dependent Variable: INCOME SMOOTHING 
Berdasarkan hasil perhitungan table uji statistik $\mathrm{T}$ diatas, cash holding dan umur perusahaan memiliki koefisien dengan arah positif, sedangkan variabel resiko keuangan dan kompensasi kerugian memiliki koefisien arah negatif. Hal ini berarti bahwa peningkatan cash holding dan umur perusahaan cenderung memiliki income smoothing yang tinggi, sedangkan peningkatan resiko keuangan cenderung memiliki income smoothing yang rendah. Berdasarkan data pada Tabel 4.5, maka dapat disimpulkan sebagai berikut:

1. Cash Holding

Tabel 4.6

Hasil Uji T Cash Holding

\begin{tabular}{|c|c|c|c|}
\hline Variabel & t-Tabel & t-Hitung & Sig \\
\hline Cash Holding & 2.003 & 1.458 & 0,150 \\
\hline
\end{tabular}

Sumber: Data yang diolah peneliti

$\mathrm{H}_{1}$ : Cash holding tidak berpengaruh signifikan terhadap income smoothing

Berdasarkan hasil perhitungan uji t diperoleh nilai t-tabel sebesar 2.003 dan t-hitung 1.458 dengan signifikansi 0.150. Nilai signifikasi tersebut lebih besar dari 0.05 ini berarti bahwa variabel cash holding tidak memiliki pengaruh yang signifikan terhadap income smoothing. Dengan demikian H1 ditolak.

2. Resiko Keuangan

Tabel 4.7

Hasil Uji T Resiko Keuangan

\begin{tabular}{|l|c|c|c|}
\hline \multicolumn{1}{|c|}{ Variabel } & t-Tabel & t-Hitung & Sig \\
\hline Resiko Keuangan & 2.003 & -5.518 & 0,000 \\
\hline
\end{tabular}

$\mathrm{H}_{2}$ : Resiko keuangan berpengaruh negatif dan signifikan terhadap income smoothing

Dari pengujian uji t diperoleh nilai t-tabel sebesar 2.003 dan t-hitung -5.518 dengan signifikansi 0.000, karena nilai signifikasi tersebut kurang dari 0.05, ini berarti bahwa variabel rseiko keuangan memiliki pengaruh yang signifikan dan negatif terhadap income smoothing. Dengan demikian $\mathrm{H} 2$ diterima.

3. Umur Perusahaan

Tabel 4.8

Hasil Uji T Umur Perusahaan

\begin{tabular}{|c|c|c|c|}
\hline Variabel & t-Tabel & t-Hitung & Sig \\
\hline Umur Perusahaan & 2.003 & 3.383 & 0,001 \\
\hline
\end{tabular}

Sumber: Data yang diolah peneliti

$\mathrm{H}_{3}$ : Umur Perusahaan berpengaruh positif dan signifikan terhadap income smoothing.

Dari pengujian uji t diperoleh nilai t-tabel sebesar 2.003 dan t-hitung 3.383 dengan signifikansi 0.001, karena nilai signifikasi tersebut kurang dari 0.05, ini berarti bahwa variabel income smoothing memiliki pengaruh yang signifikan dan negatif terhadap income smoothing. Dengan demikian $\mathrm{H} 3$ diterima.

Analisis Regresi Berganda

Tabel 4.9

Hasil Uji Regresi Linear Berganda

\begin{tabular}{|c|c|c|c|c|}
\hline Variabel & B & t-Hitung & Sig. & Kesimpulan \\
\hline Cash Holding & 11.926 & 1.458 & 0,150 & $\mathrm{H}_{1}$ ditolak \\
\hline Resiko Keuangan & -16.874 & -5.518 & 0,000 & $\mathrm{H}_{2}$ diterima \\
\hline
\end{tabular}




\begin{tabular}{|l|l|l|l|l|}
\hline \multicolumn{1}{|c|}{ Umur Perusahaan } & 0.205 & 3.383 & 0,001 & $\mathrm{H}_{3}$ diterima \\
\hline Konstanta $(\boldsymbol{\alpha})=\mathbf{9 . 4 3 0}$ & & & & \\
\hline $\mathbf{r}^{\mathbf{2}}=\mathbf{0 . 3 3 7}$ & & & \\
\hline F hitung $=\mathbf{1 0 . 9 8 6}$ &
\end{tabular}

Sumber : Data yang diolah peneliti

Berdasarkan hasil regresi pada tabel di atas, persamaan regresi linier berganda dalam penelitian ini dapat dituliskan sebagai berikut:

Uji F (Simultan)

$$
Y=9,430+11,926 X_{1}-16,874 X_{2}+0.205 X_{3}
$$

Tabel 4.10

Uji Signifikan Simultan (Uji Statistik F)

\begin{tabular}{|c|c|c|c|c|c|c|}
\hline \multirow[b]{2}{*}{ Mod } & & \multicolumn{3}{|c|}{ ANOVA $^{\mathrm{a}}$} & \multirow[b]{2}{*}{$\mathrm{F}$} & \multirow[b]{2}{*}{ Sig. } \\
\hline & & $\begin{array}{l}\text { Sum of } \\
\text { Squares }\end{array}$ & df & Mean Square & & \\
\hline \multirow[t]{3}{*}{1} & Regression & 329.216 & 3 & 109.739 & 10.986 & $.000^{\mathrm{b}}$ \\
\hline & Residual & 559.405 & 56 & 9.989 & & \\
\hline & Total & 888.620 & 59 & & & \\
\hline
\end{tabular}

a. Dependent Variable: INCOME SMOOTHING

b. Predictors: (Constant), UMUR PERUSAHAAN, RESIKO KEUANGAN, CASH

HOLDING

Sumber: Data yang diolah peneliti (output SPSS 25)

Pada tabel di atas menunjukkan bahwa nilai $\mathrm{F}$ sebesar 10.986 dengan nilai signifikansi sebesar $0,000<0,05$. Oleh karena itu model regresi yang digunakan dalam penelitian ini diterima. Sehingga model regresi dalam penelitian ini layak digunakan untuk pengujian dengan model regresi berganda.

\section{Uji Koefisien Determinasi $\left(\mathbf{R}^{2}\right)$}

Tabel 4.11

Uji Koefisien Determinasi

Model Summary ${ }^{b}$

\begin{tabular}{lr|rr|r} 
Model & $\mathrm{R}$ & R Square & Adjusted R Square & $\begin{array}{c}\text { Std. Error of the } \\
\text { Estimate }\end{array}$ \\
\hline 1 & $.609^{\mathrm{a}}$ & .370 & .337 & 3.16060 \\
\hline a. Predictors: (Constant), UMUR PERUSAHAAN, RESIKO KEUANGAN,
\end{tabular}

CASH HOLDING

b. Dependent Variable: INCOME SMOOTHING

Sumber: Data yang diolah peneliti (output SPSS 25)

Berdasarkan tabel diatas diketahui bahwa koefisien determinasi Adjusted $R$ Square diperoleh hasil sebesar 0,337 atau 33\%. Hasil ini berarti bahwa 33\% variasi income smoothing dapat dijelaskan oleh variabel cash holding, resiko keuangan, dan umur perusahaan sedangkan sisanya yaitu $67 \%$ dijelaskan oleh variabel lain diluar model yang diteliti.

\section{Pembahasan Hasil Analisis Data}

Berdasarkan hasil penelitian yang didasarkan pada pengolahan data, maka dalam penelitian ini ada beberapa hal yang dapat dijelaskan sebagai berikut:

Pengaruh Cash Holding terhadap Income Smoothing

Dari perhitungan uji t diperoleh nilai t-tabel sebesar 2.003 dan t-hitung 1.458 dengan 
signifikansi 0.150. Nilai signifikasi tersebut lebih besar dari 0.05 ini berarti bahwa variabel cash holding tidak memiliki pengaruh yang signifikan terhadap income semoothing. Dengan demikian H1 ditolak. Sehingga hasil dalam penelitian ini menunjukkan bahwa cash holding tidak berpngaruh terhadap income semoothing.

Hal ini konsisten dengan William dan Lukman (2018), yang menyatakan bahwa cash holding tidak berpengaruh terhadap income semoothing. Hasil ini juga konsisten terhadap penelitian yang dilakukan oleh Olivia dan Herlin (2019) yang menyatakan bahwa cash holding tidak akan memiliki hubungan terhadap income smoothing. Hal ini berarti, semakin rendah tingkat cash holding suatu perusahaan, maka tidak memberikan kecenderungan bagi manajemen dalam melakukan praktik perataan laba (income smoothing).

Penelitian ini menunjukkan bahwa tingkat cash holding yang ada didalam suatu perusahaan tidak menjadi pemicu manajemen untuk melakukan praktik perataan laba (income smoothing). Hal ini dapat dikarenakan praktik perataan laba (income smoothing) tidak dicapai dengan cash yang ada didalam suatu perusahaan namun dari kebijakan-kebijakan akuntansi yang berlaku. Pada dasarnya accounting principle memberikan kebebasan kepada manajemen dalam menerapkan kebijakan akuntansi yang akan digunakan oleh perusahaannya, sehingga manajemen dapat memanfaatkannya untuk melakukan praktik perataan laba (income smoothing) melalui kebebasan dalam penerapan kebijakan akuntansi tersebut. Adapun pengaruh dari perhatian publik yang hanya memperhatikan laba yang dihasilkan oleh perusahaan sehingga, keberadaan cash holding tidak membuat manajemen dalam tekanan yang dapat mendorongnya untuk melakukan praktik perataan laba (income smoothing).

\section{Pengaruh Resiko Keuangan terhadap Income Smoothing}

Dari perhitungan uji $\mathrm{t}$ diperoleh nilai $\mathrm{t}$-tabel sebesar 2.003 dan t-hitung -5.518 dengan signifikansi 0.000. Nilai signifikasi tersebut lebih kecil dari 0.05 ini berarti bahwa variabel resiko keuangan memiliki pengaruh yang signifikan terhadap income semoothing. Dengan demikian H2 diterima. Sehingga hasil dalam penelitian ini menunjukkan bahwa resiko keuangan berpngaruh terhadap income semoothing. Hasil penelitian ini mendukung penelitian Ida Ayu dan Ida Agus (2014), yang menyatakan bahwa resiko keuangan berpengaruh terhadap income. Dan juga penelitian yang dilakukan oleh Augusth (2018) yang menyatakan bahwa resiko keuangan berpengaruh terhadap income semoothing.

Berdasarkan hasil pengujian hipotesis resiko keuangan memiliki pengaruh signifikan negatif terhadap income smoothing. Hal ini berarti, semakin tinggi resiko keuangan suatu perusahaan, maka kecenderungan manajemen dalam melakukan praktik perataan laba (income smoothing) semakin rendah. Pada penelitian ini, resiko keuangan memiliki pengaruh negatif terhadap praktik perataan laba (income smoothing) dapat disebabkan apabila tingkat hutang suatu perusahaan semakin tinggi akan membuat pengawasan dari pihak eksternal khususnya kreditur terhadap perusahaan menjadi semakin ketat. Akibat pengawasan ketat yang dilakukan pihak eksternal, membuat manajer akan kesulitan untuk memanipulasi data-data keuangan, terutama bagian laba. Hal ini akan menyebabkan manajer lebih memilih untuk tidak melakukan praktik perataan laba (income smoothing) karena risiko terdeteksinya praktik ini oleh pihak eksternal/kreditur.

\section{Pengaruh Umur Perusahaan terhadap Income Smoothing}

Dari perhitungan uji t diperoleh nilai t-tabel sebesar 2.003 dan t-hitung 3.383 dengan signifikansi 0.001. Nilai signifikasi tersebut lebih kecil dari 0.05 ini berarti bahwa variabel umur perusahaan memiliki pengaruh yang signifikan terhadap income semoothing. Dengan demikian H3 diterima. Sehingga hasil dalam penelitian ini menunjukkan bahwa umur perusahaan berpngaruh terhadap income semoothing. Hasil penelitian ini mendukung penelitian Sartika dan 
Rice (2013), yang menyatakan bahwa umur perusahaan berpengaruh terhadap income. Dan juga penelitian yang dilakukan oleh Olivia dan Herlin (2019) yang menyatakan bahwa umur perusahaan berpengaruh terhadap income semoothing.

Berdasarkan hasil pengujian hipotesis umur perusahaan mempunyai hubungan yang positif dengan income smoothing. Hal ini berarti, semakin besar umur suatu perusahaan, maka kecenderungan manajemen dalam melakukan tindakan perataan laba (income smoothing) semakin tinggi. Hal ini mencerminkan bahwa semakin tingginya umur suatu perusahaan maka sudah semakin kayanya pengalaman perusahaan, sehingga kinerja dari perusahaan tersebut cenderung lebih stabil, yang ditunjukkan dengan kestabilan peningkatan dalam pencapaian laba. Hal inilah yang akan mendorong perusahaan untuk melakukan tindakan perataan laba untuk menjaga kestabilan dalam pencapaian laba yang diperoleh.

\section{SIMPULAN}

Penelitian ini bertujuan untuk menganalisis pengaruh cash holding, resiko keuangan, dan umur perusahaan terhadap income smoothing pada perusahaan perbankan tahun 2017-2019, dan setelah melalui tahap pengumpulan data, pengolahan data, analisis data dan terakhir interpretasi hasil dengan menggunakan data yang mendekati distribusi normal, tidak terdapat adanya multikolinearitas, bebas autokelasi dan tidak adanya heteroskedastisitas maka dapat disimpulkan sebagai berikut:

1. Resiko keuangan dan umur perusahaan secara bersama-sama (simultan) berpengaruh terhadap variabel income smoothing.

2. Hasil uji hipotesis secara parsial menunjukkan bahwa:

a. Cash holding menghasilkan nilai t-tabel sebesar 2.003 dan t-hitung 1.458 dengan signifikansi 0.150, dimana nilai tersebut lebih kecil dari 0,05 yang menggambarkan bahwa cash holding tidak berpengaruh signifikan terhadap income smoothing pada perusahaan perbankan yang terdaftar di Bursa Efek Indonesia tahun 2017-2019, hal ini karena praktik perataan laba (income smoothing) tidak dicapai dengan cash yang ada didalam suatu perusahaan namun dari kebijakan-kebijakan akuntansi yang berlaku.

b. Resiko keuangan menghasilkan nilai t-tabel sebesar 2.003 dan t-hitung -5.518 dengan signifikansi 0.000. Nilai signifikasi tersebut lebih kecil dari 0.05 ini berarti bahwa variabel resiko keuangan memiliki pengaruh signifikan negatif terhadap income smoothing. Resiko keuangan berpengaruh negatif terhadap income smoothing karena apabila tingkat hutang suatu perusahaan semakin tinggi akan membuat pengawasan dari pihak eksternal khususnya kreditur terhadap perusahaan menjadi semakin ketat, sehingga akan semakin sulit bagi perusahaan untuk melakukan perataan laba.

c. Umur perusahaan menghasilkan nilai t-tabel sebesar 2.003 dan t-hitung 3.383 dengan signifikansi 0.001. Nilai signifikasi tersebut lebih kecil dari 0.05 ini berarti bahwa variabel umur perusahaan memiliki pengaruh yang signifikan positif terhadap income semoothing. Hal ini berarti, semakin besar umur suatu perusahaan, maka kecenderungan manajemen dalam melakukan tindakan perataan laba (income smoothing) semakin tinggi. 


\section{REFERENCES}

Agung, A, Ida. Dan Bagus, Ida. (2014)."Perilaku Income Smoothing Dan Faktor-Faktor Yang Memengaruhinya". E-Jurnal Akuntansi Universitas Udanyana. Vol. 8, No. 1, Hal: 140153.

Andriani, Dewi. (2020). Analisis Faktor-Faktor Yang Mempengaruhi Praktik Perataan Laba (Income Smoothing) Pada Perusahaan Manufaktur Yang Terdaftar Di Bursa Efek Indonesia Tahun 2014-2018. Skripsi. Program Studi Akuntansi Fakultas Ekonomi Dan Bisnis Universitas Kristen Indonesia Paulus Makassar

Bestivano, Wildham. (2013). "Pengaruh Ukuran Perusahaan, Umur Perusahaan, Profitabilitas, Dan Leverage Terhadap Perataan Laba Pada Perusahaan Yang Terdaftar Di Bei" ( Studi Empiris Pada Perusahaan Perbankan di BEI . Skripsi. Program Studi Akuntansi Fakultas Ekonomi Universitas Negeri Padang.

Bursa Efek Indonesia. (2020). Aktivitas Dan Profil Perusahaan. Melalui Http://Www.Idx.Co.Id. Tanggal Akses 22 November - 28 November 2020.

Erika Mambraku. (2014). Pengaruh Cash Holding Dan Struktur Kepemilikan Manajerial Terhadap Income Smoothing (Studi Empiris Pada Perusahaan Manufaktur Yang Terdaftar Di Bursa Efek Indonesia Tahun 2010-2012).

Eviyanti Et All. (2019). Faktor-Faktor Yang Mempengaruhi Income Smoothing Pada Industri Barang Konsumsi Yang Terdaftar Di Bursa Efek Indonesia Periode 2014 - 2016. Jurnal Bina Akuntansi, Januari 2019, Vol.6 No.1 Hal 1 - 16.

Mambraku, M. E., \& Hadiprajitno, P. B. (2014). Pengaruh Cash Holding Dan Struktur Kepemilikan Manajerial Terhadap Income Smoothing (Studi Empiris Pada Perusahaan Manufaktur yang terdaftar di Bursa Efek Indonesia Tahun 2010 - 2012). Diponegoro Journal Of Accounting, 1-9.

Ghozali, Imam. (2016). Aplikasi Analisis Multivariete Dengan Program Ibm Spss 23. Semarang: Badan Penerbit Universitas Diponegoro.

Jensen, M.C. Dan Meckling, W.H. (1976). Theory Of The Firm: Managerial Behavior, Agency Costs And Ownership Structure. Journal Of Financial Economics, 3(4), Pp. 305-360.

Noviana, S. R., \& Yuyetta, E. N. (2011). Analisis Faktor-Faktor Yang Mempengaruhi Praktik Perataan Laba (Studi Empiris Perusahaan Manufaktur Yang Terdaftar Di Bei Periode 2006-2010). Jurnal Akuntansi \& Auditing Vol. 8.November 2011 , 1-94.

Rice dan Sartika Salim. (2014). "Pengaruh Faktor Eksternal Dan Internal Perusahaan Terhadap Tindakan Perataan Laba.”Jurnal Wira Ekonomi Mikroskil, 4 (2): 91-100.

Riyadi, Wulan. (2018). Pengaruh Cash Holding, Profitabilitas Dan Nilai Perusahaan Terhadap Income Smoothing (Studi Empiris Pada Perusahaan Manufaktur Yang Terdaftar Di Bursa Efek Indonesia Tahun 2013-2015). Fakultas Ekonomika Dan Bisnis Universitas Majalengka. Jurnal Ilmiah Manajemen \& Akuntansi Tahun 2018 Vol. 5 Nomor 1 Periode Januari - Juni Issn : 2356-3923.

Roempoembo, Agusth. (2018). Faktor-Faktor Yang Memengaruhi Income Smoothing (Studi Empiris Pada Perusahaan Perbankan Yang Terdaftar Di Bei Tahun 2013-2016).

Fakultas Ekonomi Dan Bisnis Universitas Musamus Merauke.

Sanjaya, W., \& Suryadi, L. (2018). Faktor-Faktor Yang Mempengaruhi Income Smoothing Pada Perusahaan Manufaktur Periode 2014-2016. Jurnal Ekonomi/Volume XXIII, No. 03, 347358.

Sellah Dan Vinola Herawaty. (2019). Pengaruh Profitabilitas, Leverage, Reputasi Auditor, Nilai Perusahaan, Dan Umur Perusahaan Terhadap Praktik Perataan Laba Dengan Kepemilikan 
Manajerial Sebagai Variabel Moderasi. Jurusan Akuntansi Universitas Trisakti. Seminar Nasional Cendekiawan Ke 5 Tahun 2019 Issn (P) : 2460 - 8696 Buku 2: "Sosial Dan Humaniora "Issn (E) : 2540 - 7589.

Sugiyono. (2016). Statistik Untuk Penelitian. Bandung : Alfabeta.

Suryandari, Ni Nyoman (2012). Analisis Faktor-Faktor Yang Mempengaruhi Income Smoothing. Universitas Mahasaraswati Denpasar. Media Komunikasi Fis Vol. 11 .No 1 April 2012 : 1 - 15 Issn $1412-8683$.

Tamara, Olivia Dan Herlin Tjundjung. (2019). Faktor-Faktor Yang Mempengaruhi Income Smoothing Pada Perusahaan Manufaktur. Program Studi Akuntansi Fakultas Ekonomi Universitas Tarumanagara, Jakarta. Jurnal Multiparadigma Akuntansi, Volume I No. 3/2019 Hal: 655-665.

Tevi Et All. (2019). Pengaruh Risiko Keuangan Dan Nilai Perusahaan Terhadap Perataan Laba. Program Studi Akuntansi, Fakultas Ekonomi, Universitas Sangga Buana. SIKAP, Vol 4 (No. 1), 2019, Hal 95-101 P-Issn: 2541-1691 E-Issn : 2599-1876 